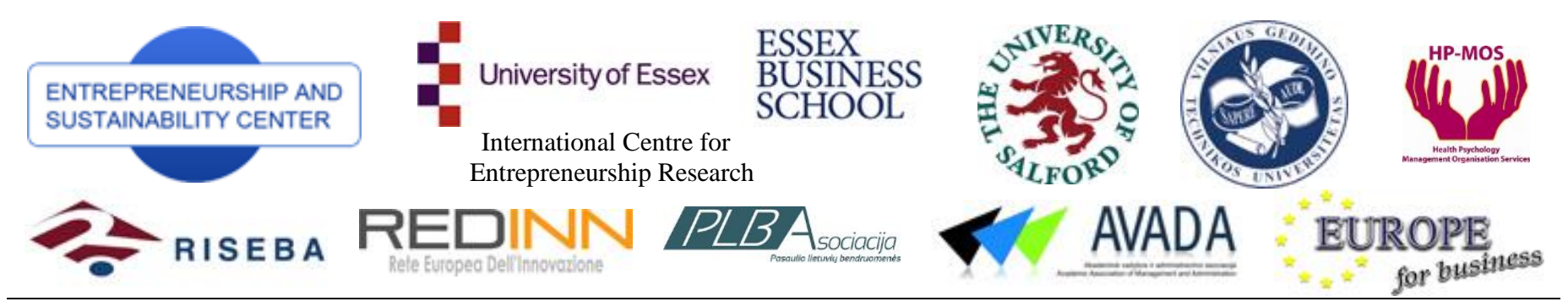

The International Journal

ENTREPRENEURSHIP AND SUSTAINABILITY ISSUES

ISSN 2345-0282 (online) http://jssidoi.org/jesi/aims-and-scope-of-research/

\title{
SUSTAINABLE ENTREPRENEURSHIP AND WOMEN IN SCIENCE AND EDUCATION: GENDER EQUALITY, GENDER INEQUALITY
}

\author{
Natalia Vinokurova \\ Central Economics \& Mathematics Institute Russian Academy of Sciences \\ Nakhimovsky prospect, 47, 117418 Moscow, Russia \\ E-mail:vinokurova@yandex.ru
}

Received 15 September 2014, accepted 20 January 2015

\begin{abstract}
Sustainable development of societies, businesses, and, ultimately, countries among other factors, is affected by such important driving force, as gender equality. The paper is dedicated to study of gender situation in science and education. It is demonstrated the process of feminization in theses spheres and the tendency towards gender balance. At the same time gender inequality persists, first of all it concerns science. Issues of low salaries and poor working conditions are acute for women. As demonstrated in the paper the inequality affects women's everyday lives and social well-being.
\end{abstract}

Keywords: Sustainable entrepreneurship, gender equality, gender inequality, social well-being, women's poverty, women in science, women in education

Reference to this paper should be made as follows: Vinokurova, N. 2015. Sustainable entrepreneurship and women in science and education: gender equality, gender inequality, Entrepreneurship and Sustainability Issues 2(4): 220-232.

DOI: http://dx.doi.org/10.9770/jesi.2015.2.4(5)

JEL Classification: A130, D630, E6, J160

\section{Introduction}

Sustainable economic development in big extent is dependent on sustainability of entrepreneurial processes (Tvaronavičienè, Lankauskienè 2011; Ercsey 2012; Laužikas, Dailydaitė 2013; Lankauskienė, Tvaronavičienė 2012; Mačiulis, Tvaronavičienė 2013; Balkienè 2013; Tunčikienė, Drejeris 2015; Giessen 2015; Lankauskienė 2014; Tarabkova 2014; Peker et al. 2014; Prause 2014; Caurkubule, Rubanovskis 2014; Litvaj, Poniščiaková 2014; Figurska 2014; Išoraitė et al. 2014; Tvaronavičienė 2014; Bileišis 2014; Wahl, Prause 2013; De Alencar, Almeida 2013; Raišienè, Jonušauskas 2013; Išoraitė 2013; Laužikas, Mokšeckienè 2013; Dzemyda et al. 2015; Mostenska, Bilan 2015; Bilevičienè, Bilevičiūtė 2015; Goyal, Sergi 2015; Tvaronavičienė et al. 2014; Vasiliūnaite 2014). Those processes in their turn are directly affected by women role in science and education (Mačiulis, Tvaronavičienė 2013; Balkienė 2013; Tunčikienè, Drejeris 2015; Giessen 2015; Lankauskienė 2014; Tarabkova 2014; Peker et al. 2014; Prause 2014; Caurkubule, Rubanovskis 2014; Litvaj, Poniščiaková 2014; Figurska 2014; Išoratè et al. 2014; Tvaronavičienė 2014; Bileišis 2014; Vasiliūnaitė 2014). 
In Russia the fields of science and education are widely regarded as the most developed in terms of gender equality. Indeed, from the early years of Soviet power women had access to formal education, including higher education. The fact that education in the USSR was free facilitated a massive flow of women into higher educational establishments. In the early 1970s about 7\% of GDP went to support education (Voronina 1998). The state of affairs in education was significantly better than in other parts of the national economy. The difference was primarily in the ratio of men to women working in education. For example, in 1985, the percentage of women in education was 78\%, and in manufacturing only half as much 42\% (Narodnoe khoziaistvo SSSR 1988, 1989) Also we argue that the difference was in the ratio of the men's to women's salaries, though we cannot give exact figures as in Soviet times there were no gender statistics of this kind. Even in the special statistical digest of 1995 "Women of Russia," there was no data on women's salaries (Zhenshchiny Rossii 1995). In the postSoviet period the percentage of women in education changed insignificantly ( $81 \%$ in education, and $41 \%$ in manufacturing). The ratio of female to male salaries in education was $86 \%$, whereas in manufacturing it was less than 70\%. So it is a continuing trend (Zhenshchiny i muzhchiny Rossii 2010). There was steady progress in expanding the proportion of women involved in science. In fact the data shows a steady increase in the percentage of women in science during the entire history of the development of the national science base, and in some periods the rate of growth of women in science was actually at the expense of male scientists (Agamova, Allathverd'an 2001). Thus, during the Soviet era, the gender equality situation in science and education in Russia was better than in many European countries in those days (Stolte-Heiskanen 1991).

Science and education became, as it were, a showcase for Soviet achievements in the area of equal rights and opportunities for men and women. The myth of total equality between men and women working in the field of science and education collapsed in the post-Soviet era. Much has been written about discrimination against women (Voronina 1998; Antonova 2010; Beljaeva et al. 2000; Haritonova 2013 and others). From the first years of perestroika in Russia, the women's movement started to develop rapidly, and research into gender issues was launched at universities. Researchers got access to gender statistics. In general, society became more democratic. One might expect that equality between men and women was at last to become reality. Yet, even to this day, in the fields of science and education one can observe gender processes developing in different directions.

This study posits a paradoxical (or contradictory) situation in the sphere of science and higher education at the moment - a clear tendency towards gender equality on the one hand, but also a significant gender disparity on the other. My research is based on official national statistics on gender and on the results of the quantitative sociological investigation of men and women working across disciplines in the sciences, in the Russian Academy of Sciences or in universities. The figures speak for themselves.

\section{Feminization of the realms of "science" and "education": the quantitative aspect}

Russia is a country of highly educated women. They account for approximately 57\% (Table 1) of the student body.

Table 1. Percentage of women students in institutions of higher education

\begin{tabular}{|c|c|c|c|c|c|c|}
\hline Years & $1985 / 86$ & $1990 / 91$ & $1994 / 95$ & $1999 / 2000$ & $\mathbf{2 0 0 7 / 0 8}$ & $\mathbf{2 0 0 8 / 2 0 0 9}$ \\
\hline$\%$ & 56 & 51 & 53 & 55 & 57 & 57,2 \\
\hline
\end{tabular}

Source: Zhenshchiny i muzhchiny Rossii 2000; 2004; 2008; 2010

The percentage of women students somewhat declined in the most economically severe1990s, but by 2008 had already exceeded the pre-perestroika level. In state universities in the academic year 2008-2009, women comprised 56.9\% of the students, and in private institutions-62.2\% (Obrazovanie v Rossii 2003, 2010). In 2007, of those with a higher level of education employed in the national economy, $53.7 \%$ were women. Women professionals possessing the highest level of qualification in the national economy constituted $61 \%$, while among experts with an average qualification level, women constituted about 68\% (Zhenshchiny i muzhchiny Rossii 
2008). ${ }^{1}$ The representation of women in the sphere of science education in Russia is satisfactory enough. In fact, these sectors are experiencing feminization. Education is especially feminized due, primarily, to the great number of female teachers in high schools. But even in colleges and universities, women make up more than half of the science faculty-55\% (Table 2) (Zhenshchiny i muzhchiny Rossii 2008; 2010). At private universities, the percentage of women professors and lecturers is higher than in the state institutions (Table 3).

Table 2. Teachers of the state and municipal educational institutions by types of establishments (percentage of women)

\begin{tabular}{|l|c|c|}
\hline & $\begin{array}{c}\text { Academic year 2007- } \\
\mathbf{2 0 0 8}\end{array}$ & Academic year 2009-2010 \\
\hline Total & 79 & 79 \\
\hline Teachers in high schools (obscheobrazovatel'naia shkola) & 86 & 67 \\
\hline $\begin{array}{l}\text { Teachers in educational institutions for primary vocational } \\
\text { training (PTU) }\end{array}$ & 73 & 79 \\
\hline $\begin{array}{l}\text { Teachers of secondary specialized educational institutions } \\
\text { (tekhnikum) }\end{array}$ & 76 & 55 \\
\hline Teachers of higher educational institutions (faculty) & 54 & \\
\hline
\end{tabular}

Source: Nauka Rossii v tsifrakh 2011

Table 3. Increase in the number of women on the teaching staff of higher educational institutions; $\%$ at the beginning of the year

\begin{tabular}{|c|c|c|c|c|c|c|c|c|c|c|c|}
\hline \multirow[b]{2}{*}{ Years } & \multicolumn{6}{|c|}{ State educational institutions } & \multicolumn{5}{|c|}{ Private educational institutions } \\
\hline & 1995 & 2000 & 2001 & 2002 & 2006 & 2009 & 2000 & 2001 & 2002 & 2006 & 2009 \\
\hline $\begin{array}{l}\text { Percentage of } \\
\text { female } \\
\text { employees (full- } \\
\text { time) }\end{array}$ & 44.4 & 49.1 & 50.3 & 51.0 & 53.3 & 54.7 & 56.9 & 56.7 & 58.5 & 54.0 & 57.6 \\
\hline $\begin{array}{l}\text { Percentage of } \\
\text { female } \\
\text { employees (part- } \\
\text { time) }\end{array}$ & 27.6 & 34.8 & 36.3 & 38.4 & ----- & ----- & 52.5 & 54.5 & 54.8 & 52.6 & 52.6 \\
\hline
\end{tabular}

Source: Calculations of author based on Obrazovanie v Rossijskoj Federatsii 2010

The state higher educational institutions, especially large prestigious universities and institutes, are more conservative on gender issues in comparison with private universities. This is confirmed not only by the data cited, but also by the results of other studies (Agamova, Allathverd'an 2001; Eflova, Fursova 2007). In the sphere "science and scientific service," women number more than half as well. And they dominate in small business that is related to science and education. According to the experts, up to $56 \%$ of private enterprises in this sphere belong to women (Oreshenkova 2007).

\section{Feminization of the realms of "science" and "education": the qualitative aspect}

The process of the feminization of science and education is characterized not only by quantitative, but also qualitative, changes. The number of female post-graduate students (aspirantki) and candidates for the higher doctorate (doktorantki) (Table 4) is increasing. Do note that there are two scientific degrees in Russia: Candidate of science (Kandidat) and a higher level of doctorate-Doctor of Sciences (Doktor nauk). Both are considered roughly equivalent to the $\mathrm{Ph} . \mathrm{D}$, but it is much more difficult to get the degree of Doctor of Science.

\footnotetext{
${ }^{1}$ These data concern occupational groups. The group with the highest level of qualification includes, for instance, engineers, doctors, architects, and scientists. The group with an average qualification level includes, for example, hospital nurses, teachers in preschool institutions or in primary schools, and technicians.
} 
Table 4. Increase in the number of female graduate students and candidates for the doctorate

\begin{tabular}{|c|c|c|c|c|c|}
\hline Years & $\mathbf{1 9 9 8}$ & $\mathbf{1 9 9 9}$ & $\mathbf{2 0 0 0}$ & $\mathbf{2 0 0 8}$ & $\mathbf{2 0 0 9}$ \\
\hline Female graduate students (aspirantki) & 41.7 & 43.2 & 44.0 & 44.6 & 45.9 \\
\hline $\begin{array}{c}\text { Candidates for the doctorate } \\
\text { (doktorantki) }\end{array}$ & 33.9 & 35.9 & 37.8 & 47.1 & 47.1 \\
\hline
\end{tabular}

Source: Zhenshchiny i muzhchiny Rossii 2000; 2004; 2008; 2010

The difficult late nineties of the last century in Russia witnessed a massive reduction of personnel in science. Women were affected more than men. The proportion of women among researchers has fallen, but the percentage of women who get advanced scientific degrees has been rising constantly (Table 5).

Table 5. Percentage of female researchers

\begin{tabular}{|c|c|c|c|}
\hline Years & $\begin{array}{c}\text { Total } \\
\boldsymbol{\%}\end{array}$ & $\begin{array}{c}\text { Among Doctors of Sciences (Doktor nauk) } \\
\mathbf{\%}\end{array}$ & $\begin{array}{c}\text { Among Candidates of Sciences (Kandidat nauk) } \\
\text { \% }\end{array}$ \\
\hline $\mathbf{1 9 9 4}$ & 48.7 & 16.9 & 31.9 \\
\hline $\mathbf{1 9 9 8}$ & 45.2 & 18.5 & 33.5 \\
\hline $\mathbf{2 0 0 0}$ & 44.1 & 18.8 & 33.9 \\
\hline $\mathbf{2 0 0 8}$ & 41.8 & 22.0 & 37.9 \\
\hline $\mathbf{2 0 0 9}$ & 41.9 & 22.4 & 38.2 \\
\hline
\end{tabular}

Source: Nauka Rossii 2003

The largest percentage of female researchers is in the humanities. In 2010, women made up 63.4\%of the total number of researchers in the humanities, "doctors of sciences": $42.4 \%$ and "candidates of sciences": $63.5 \%$ (Nauka Rossii v tsifrakh 2011). Since 2000, the number of female researchers in technical sciences has declined steadily. Our research conducted in 1997 and 2008 confirmed the increase of women's interest in scientific work and an academic career (Figure 1).We see that in 2008, the proportion of female students and post-graduate students participating in scientific conferences was significantly more than it was in 1997, although the total number of female graduates students in these years was less than that of male graduate students. Thus, in 2007 , women made up $42.9 \%$ of the total number of postgraduates, but of those less than 25 years of age, women made up only $34.6 \%$ (Indikatory nauki 2009). Many of the young men entered postgraduate course to avoid Army service.

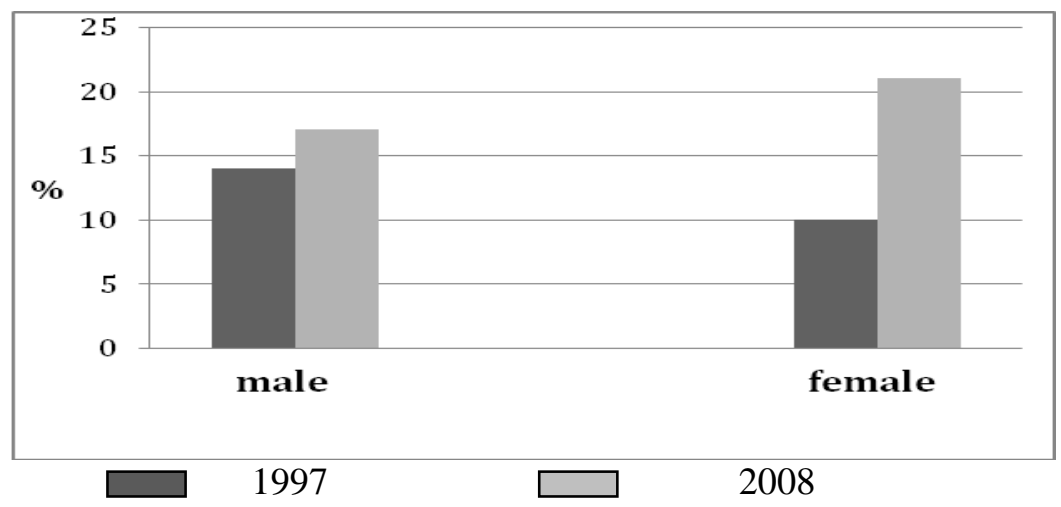

Fig.1. Post-graduate and undergraduate students participating in scientific conferences in 1997 and2008 (Results of our surveys in 1997 and 2008)

Source: Prepared by author 
The percentage of female thesis and dissertation advisors is increasing (Table 6). Also, the number of female administrators in higher education is growing. In the academic year1999-2000, 22\% of the deans of faculties were women. By 2009-2010, that figure grew to $37 \%$ (Table 7).

Table 6. Percentage of female thesis and dissertation advisors for scientific degrees

\begin{tabular}{|c|c|c|c|c|c|c|c|c|c|c|}
\hline Years & $\mathbf{2 0 0 0}$ & $\mathbf{2 0 0 1}$ & $\mathbf{2 0 0 2}$ & $\mathbf{2 0 0 3}$ & $\mathbf{2 0 0 4}$ & $\mathbf{2 0 0 5}$ & $\mathbf{2 0 0 6}$ & $\mathbf{2 0 0 7}$ & $\mathbf{2 0 0 8}$ & $\mathbf{2 0 0 9}$ \\
\hline $\begin{array}{c}\text { Candidates of } \\
\text { sciences }\end{array}$ & 30 & 31 & 32 & 33 & 35 & 36 & 37 & 38 & 38 & 39 \\
\hline $\begin{array}{c}\text { Doctors of } \\
\text { sciences }\end{array}$ & 17 & 18 & 19 & 19 & 20 & 21 & 22 & 24 & 25 & 26 \\
\hline
\end{tabular}

Source: Zhenshchiny i muzhchiny Rossii 2000; 2004; 2008; 2010

\section{Gender inequality in science education and its consequences}

Science and education are characterized by the same gender inequality that we find throughout the labor market. First, the feminization of science and education is directly related to low wages in these disciplines. The average salary in education in 2007 was 30\% below the average wage in Russia. By 2011, the wages in education were 1.5 times less than the average (Rossiia $\mathrm{v}$ tsifrakh 2012). By comparison, wages in finance were 2.62 times higher than the average. The worst situation is in Moscow, where there are many universities and institutes of the Russian Academy of Sciences (Varshavskii 2009). The prestige of science began to fall in the 1990s. Young men left jobs in science to work in other, more prestigious and highly paid, fields. This explains why women today prevail among researchers in the age group of 30-50.

Second, women in science and education are still concentrated at the lower levels of the hierarchy. They have very good educational capital, but they are lacking both the capital of academic and scientific power and the capital of scientific prestige. This is well illustrated by the representation of women among the teaching staff of Russian universities (Table 7).

Table 7. The percentage of women on the staff of state and municipal higher educational institutions for academic years 2005-2006, 2007-2008 and 2009-2010

\begin{tabular}{|c|c|c|c|}
\hline \multirow{2}{*}{ Faculty and Administrators } & \multicolumn{3}{|c|}{ Women (\%) } \\
\hline & $2005-2006$ & 2007-2008 & $2009-2010$ \\
\hline Total & 53 & 54 & 55 \\
\hline \multicolumn{4}{|l|}{ Including: } \\
\hline vice-chancellors & 8 & 8 & 9 \\
\hline deputy vice-chancellors & 26 & 26 & 29 \\
\hline Deans & 34 & 36 & 37 \\
\hline chairs (heads of departments) & 33 & 35 & 37 \\
\hline Professors & 24 & 26 & 28 \\
\hline assistant professors, senior lectures & 49 & 52 & 54 \\
\hline Lecturers & 70 & 70 & 71 \\
\hline Assistants & 69 & 69 & 68 \\
\hline
\end{tabular}

Source: Zhenshchiny i muzhchiny Rossii 2004; 2008; 2010

We see that women comprise only $9 \%$ of the vice-chancellors of higher educational institutions, and of deputy vice-chancellors, only $29 \%$. It is impossible to ignore the fact that women are more likely to achieve higher status as an administrator than as a member of the faculty. While the percentage of women among deans is $37 \%$, women comprise only $28 \%$ of the cadre of (full) professors. From the example of the University of Kazan we can see the usual gender composition of administration and faculty: the rector and vice-rector are men; among 60 members of the Academic Council, only 6 are women; among 29 distinguished professors, only 4 are women (Eflova and Fursova 2007). 
A woman's path toward career and scientific achievements is longer in comparison to a man's. Women take more time to complete their doctoral dissertations. In data from 1999, women took from 17 to 35 years to complete the dissertation for Doctor of Science (Doktor nauk), whereas half of the men took under 20 years to complete the requirement (Vinokurova 1999). Also, women usually begin their scientific career later than men do. In 2007, among those completing doctorates under the age of 35, 42.3\% were women, but of those 35-49 years of age, $52.8 \%$ were women. However, among those receiving the doctorate at an even older age, men again prevail (calculations of the author according to Indikatory nauki 2009).

Our study reveals that traditional stereotypes of gender roles are particularly strong in science. According to our respondents, the most routine and unattractive research is traditionally assigned to women. Women's rights are in fringed upon in the publication of papers made in cooperation with men - they might be cited as a subordinate co-author, or not cited at all. Moreover, women-administrators are more often assigned routine jobs and cannot make important decisions - this prerogative more likely goes to male chairs or professors. All the researchers write about such discrimination against women working in science and education (Agamova and Allathverd'an 2001; Bogdanova 2004; Eflova, Fursova 2007; Koshkina 2005; Mirskaja, Martynova 1993; Zhenshchiny i muzhchiny Rossii 2010).

Women working in education earned approximately 25\% less than their male colleagues earned in 2000, and $27 \%$ less in 2002 (Obrazovanie v Rossii 2003). ${ }^{2}$ In 2011, the salaries of female teachers in universities were $18 \%$ lower than those of male teachers. The gap in earnings is even higher in scientific institutions (according to the most recent available data, for 1999, women earned 32\% less (Bogdanova 2004). In other fields of the national economy, the difference between men's and women's earnings is even greater. For example, in 2007, in the field of information technology, wages of women lagged $60 \%$ behind those of men (Zhenshchiny i muzhchiny Rossii 2008). Nonetheless, it is evident that as a result of the loss of prestige in the sciences, the poor material provisions for scientists and university professors, low wages, and, finally, gender discrimination, women in science and education have become highly disadvantaged.

Our results confirm that the living standards of men and women in education and science vary. They are based on a questionnaire survey of research scientists that was conducted in 2008. The sample consisted of representatives of thirteen fields of science, mostly mathematicians, economists, and biologists. We investigated both women and men. The survey covered twenty- two population centers. The participants' main field of activity was either scientific research, as a rule combined with teaching, or teaching in institutions of higher learning, in addition to science work. Half the respondents held doctor or candidate degrees. In addition, 25\% were administrators of varying ranks (heads of departments, laboratories, divisions). One fifth were graduate and undergraduate students. So the group under review represents the most active stratum of the academics engaged in research. A similar survey was conducted in 1997; the results were published in the Russian Academy of Sciences journal Sociologicheskie issledovanija (Vinokurova 1999). The differences between women and men participating in the survey are quite large according to several parameters. Women administrators comprise only $13 \%$; men - nearly half. Women "doctors of sciences" comprise 7\%; men-more than $40 \%$. However, $35 \%$ of the women hold the degree of "candidate of sciences" as opposed to $17 \%$ of the men.

A striking observation of the 2008 questionnaire is that $68 \%$ of women researchers believe that their wages are below average in the region of their residence, while only $45 \%$ of the men surveyed share these feelings (Figure 2).

${ }^{2}$ Private institutions are not included. 


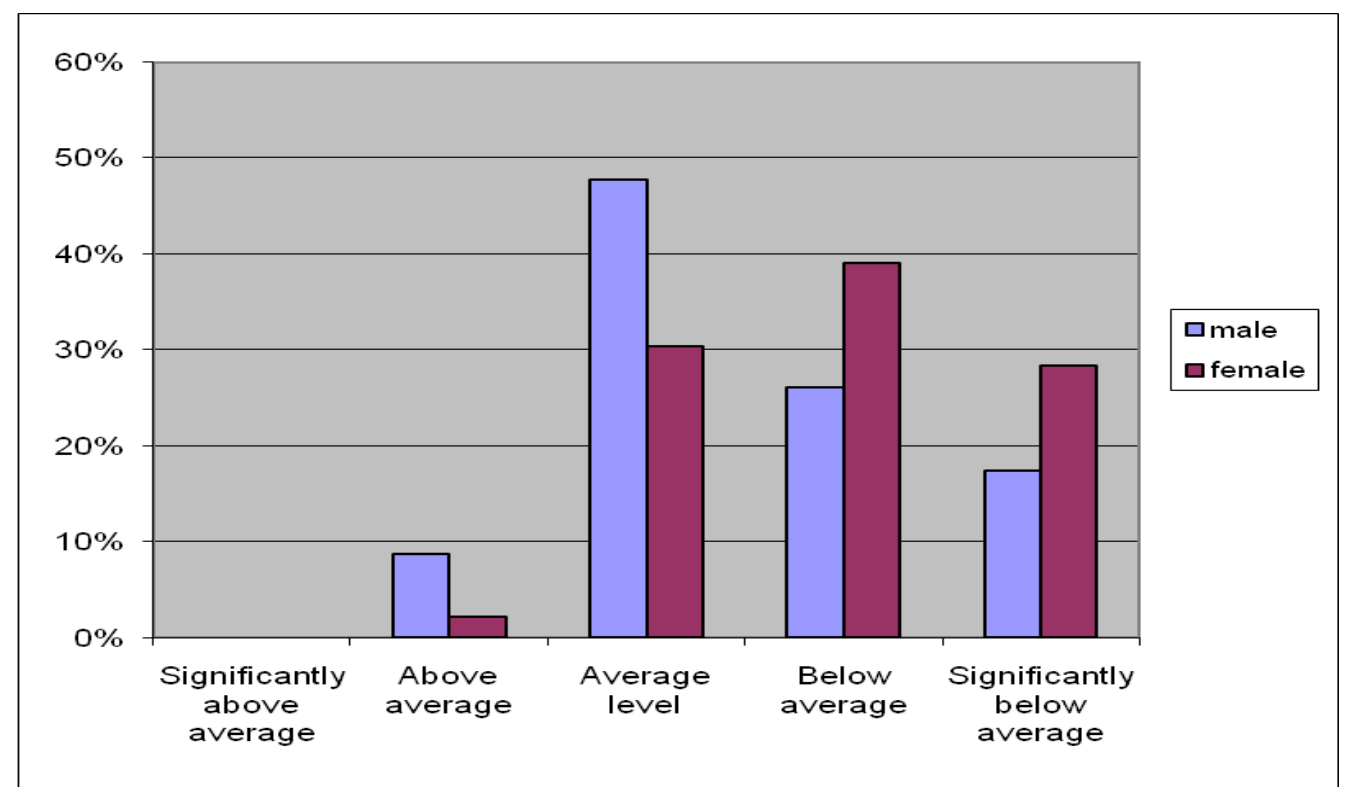

Fig. 2. The respondents' perception of their level of wages compared to the average wage in the region of their residence

Source: Prepared by author

Both men and women have to look for a second job. But $67.4 \%$ of the women believe that they could refuse a second job only if their salaries increased by at least 200\%. In Soviet times, representatives of science and education considered themselves middle- class. Today more than half the men in these fields $(52.2 \%)$ continue to believe that they belong to the middle class; no one considers himself to be very poor. But $50 \%$ of women consider themselves to be poor, and $4.4 \%$ to be very poor. Indeed, women cannot pay for services commonly available to the middle class. Thus, women are less likely to be able to pay for medical services. This is a major problem, because it is almost impossible at present to get free medical services of good quality (Figure 3). We see that the disparity between men's and women's ability to pay for medical care is significant. Only in rare situations can women pay for the services of a dentist. Compared to men, only half of the women can pay for medical consultation and so on.

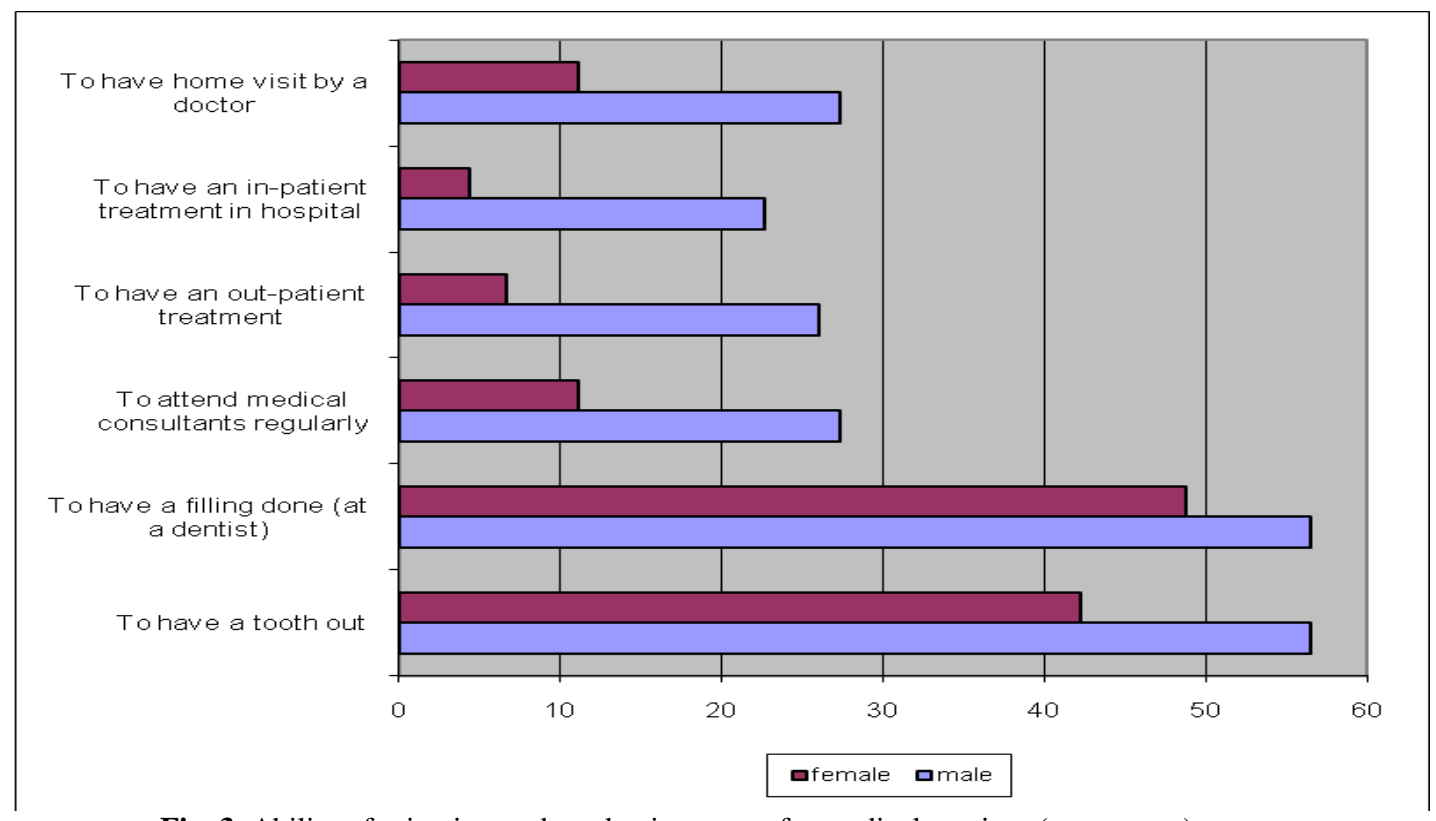

Fig. 3. Ability of scientists and academics to pay for medical services (percentage)

Source: Prepared by author 
$66.7 \%$ of the female scientists and academics, compared to $40.9 \%$ of the males, think that it is necessary to increase their salaries more than $200 \%$ in order to get medical services of good quality. However, only $2.2 \%$ of the women could pay for medical services if their salary were merely doubled. Nobody among the women could pay for medical services if their salary were increased by only $50 \%$.

$26 \%$ of the men, but only17\% of the women, have the opportunity to spend their vacation at a resort (in a sanatorium or "dom otdykha"). Almost a third of the women think that it is necessary to increase their salary by $200 \%$ in order to purchase good food. Thus the recovering and preservation (maintenance) of women's health is a great problem for female researchers and academics.

Scientists and academics give great importance to the education of their children. They want their children to get an education at least not worse than their own. They believe that only a good education and a prestigious profession will enable their children to get good jobs. But women generally find it impossible to pay for the education of their children at good universities. In this sense, men are in a better position (Figure 4). We see that less than a third of the women can pay an annual tuition fee of $\$ 2,000$. The tuition at prestigious, well-known universities is a great deal higher. For example, a year's tuition, figured in dollars in 2008, was as follows: Moscow State Institute of International Relations, \$9,976; Higher School of Economics State University, \$9,392; Southern University, \$6,000; Far Eastern State Medical University, \$3,160. (Varshavskii 2009). In contrast to wages, the tuition fee is constantly increasing.

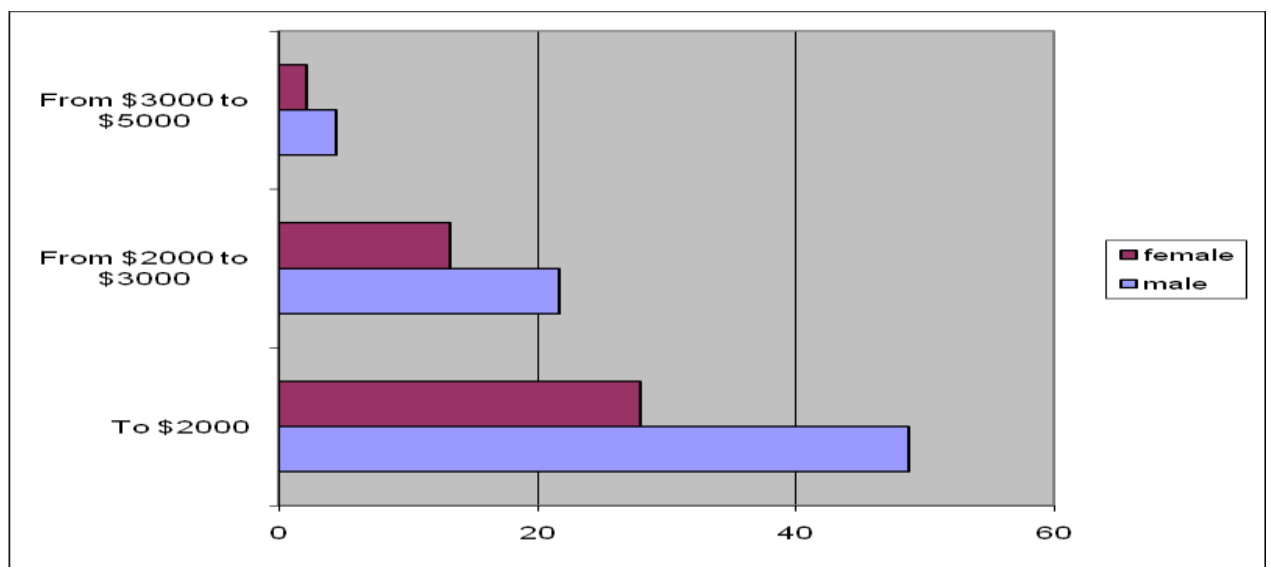

.Fig 4. Ability to pay for the higher education of children (percentage)

Source: Prepared by author

The poor financial position of women in science and academia affects not only their everyday life. Women have fewer opportunities to upgrade their qualifications, to keep up with new scientific achievements in their field. For example, they find it difficult to afford the necessary scientific literature or to subscribe to necessary journals (Figure 5).In addition, $72.7 \%$ the women, compared to $62.5 \%$ of the men, cannot afford to buy the scientific books required for their research.

Today it is often argued that all necessary information can be found on the internet. But, for these men and women, it is simply no so- one out of four women does not have access to a computer. The situation with peripheral equipment maintenance is even worse (Figure 6).

$36.3 \%$ of the women cannot obtain, under any circumstances, the money needed to travel to conferences abroad. The figure for the men-29.2\%.Women give great value to upgrading their qualifications, and they are ready to spend their own money for this purpose. For example, $66.6 \%$ of the women believe that an increase in their wages would allow them to pay for participation in conferences, to buy necessary books and journals, and to buy a printer, etc. Among the men, only $56.5 \%$ are ready to spend their own money for these purposes. 


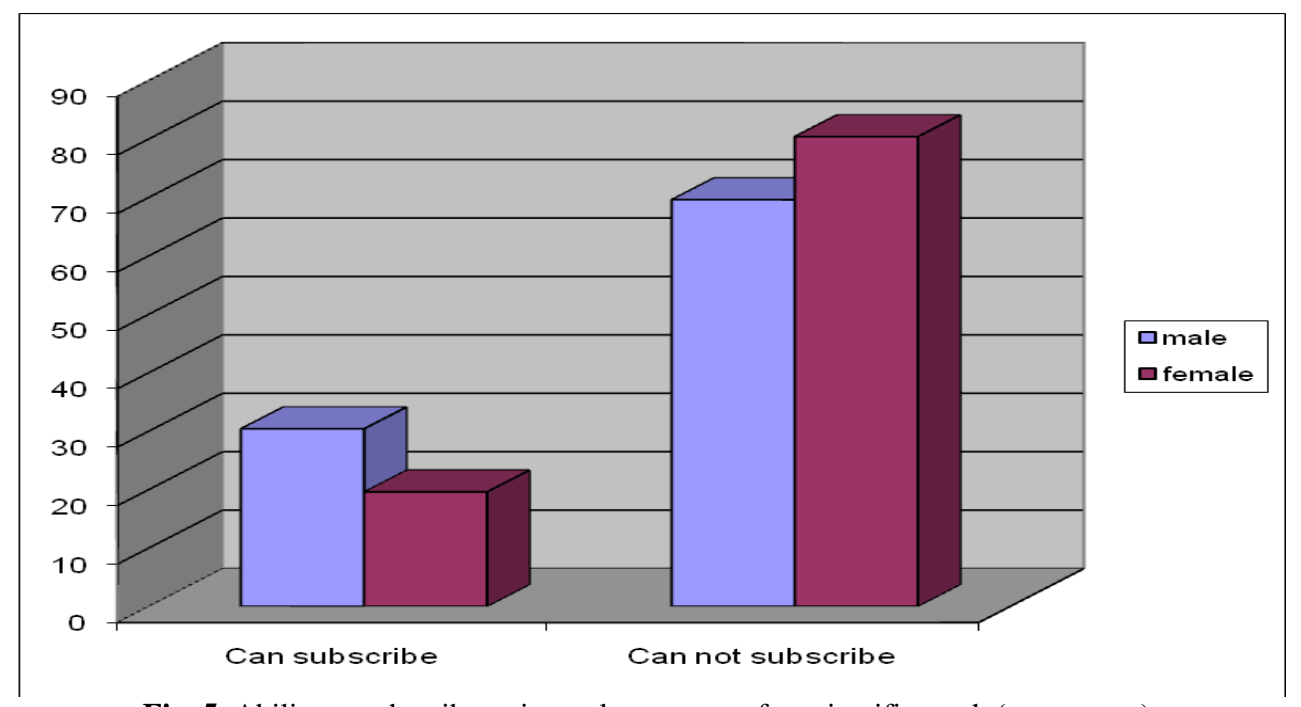

Fig. 5. Ability to subscribe to journals necessary for scientific work (percentage).

Source: Prepared by author

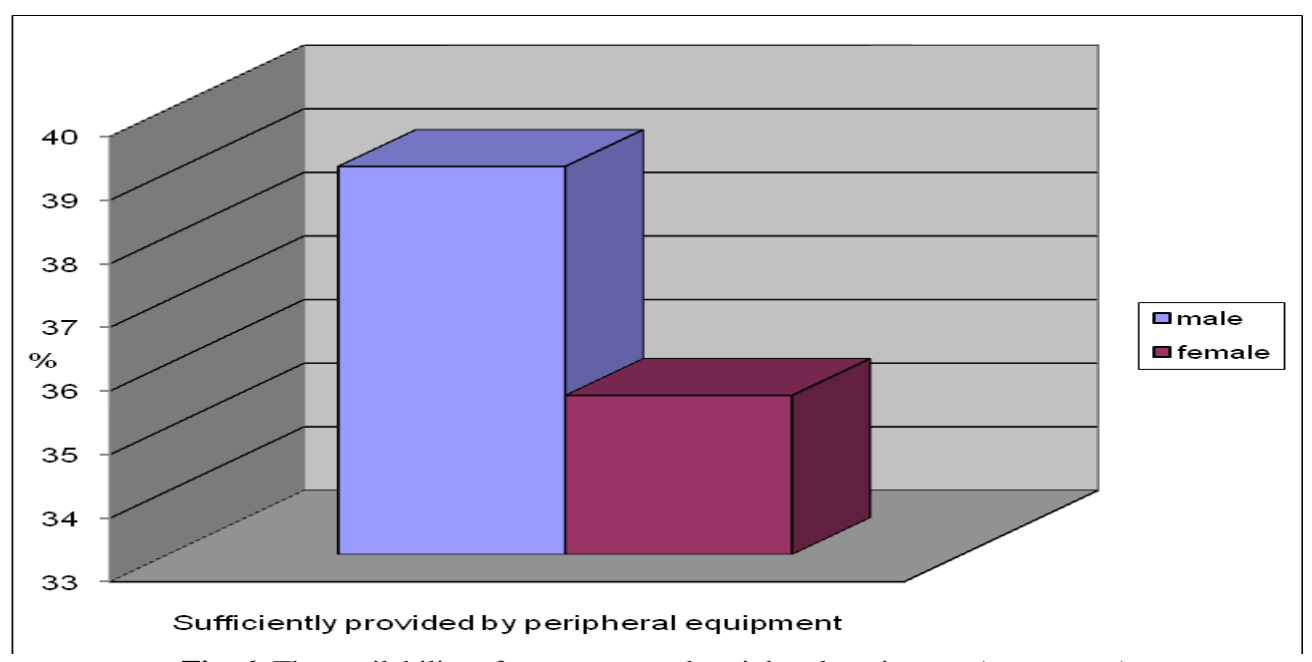

Fig. 6. The availability of computers and peripheral equipment (percentage)

Source: Prepared by author

Poverty, poor working conditions, and the lack of technical support could not but affect the mood of women (Figure 7). The women's general satisfaction with life is lower than that of the men. Also, the women feel that they are less in control (Figure 8). Only about $10 \%$ of the women believe that they have a certain degree of power. Taking into account that $13 \%$ of the female respondents in our sample were managers, we can argue that even female heads of departments, laboratories, etc. feel that they have less power and fewer rights.

The women in our study are highly aware of the issues of inequality and injustice, whether it concerns the situation in Russia as a whole or their personal situation. And they have to deal with inequality and injustice in their lives more often than men do. Thus, 59\% of the women have experienced inequality in pay. Among the men, this figure was only $48 \% .50 \%$ of the women, in their opinion, have faced inequality and injustice in career opportunities. Only $35 \%$ of the men had had this experience. 


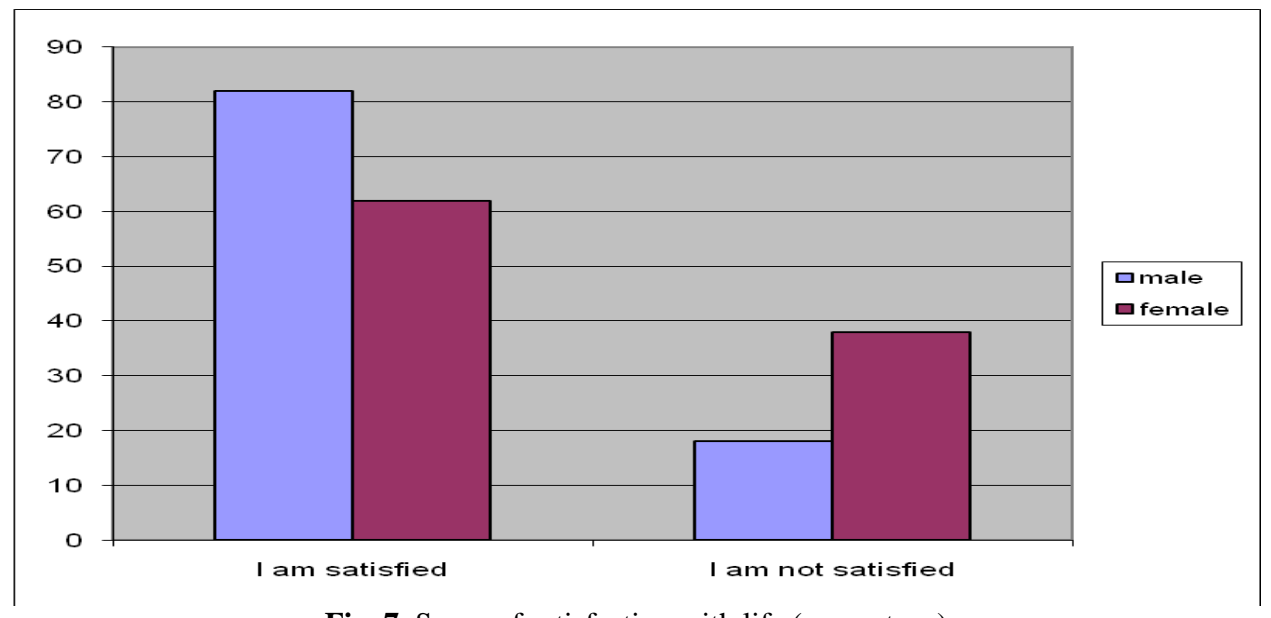

Fig. 7. Sense of satisfaction with life (percentage)

Source: Prepared by author

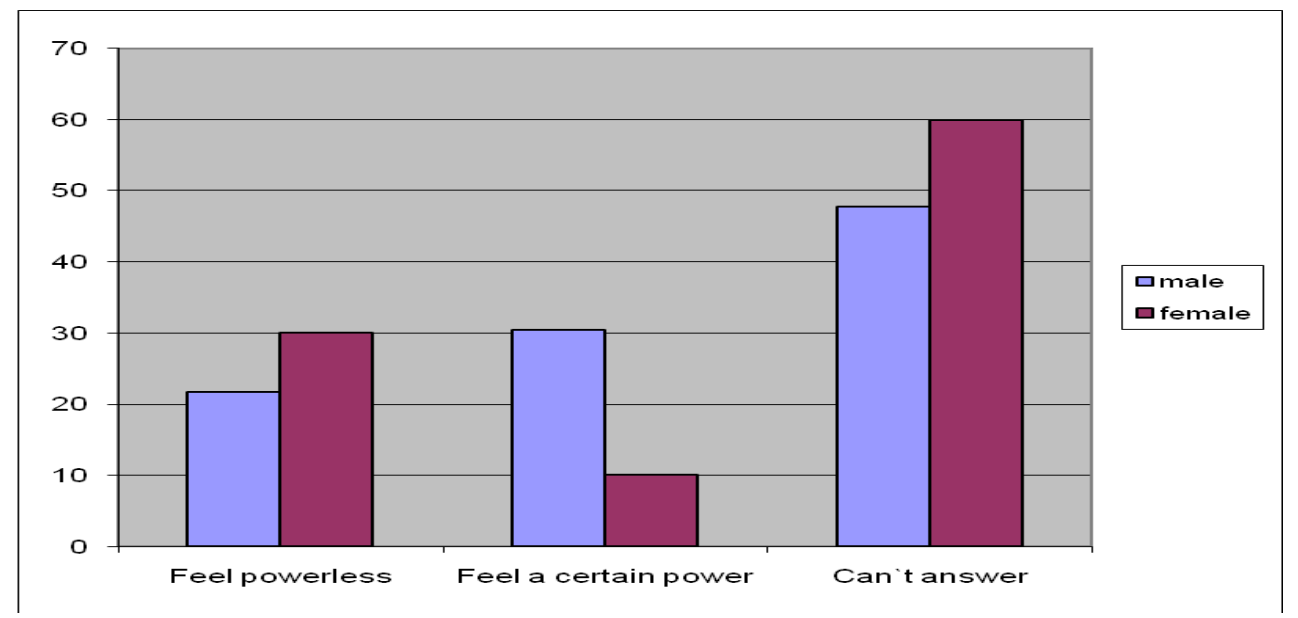

Fig. 8. Sense of powerlessness /not being in control (percentage)

Source: Prepared by author

Finally, women are more likely than their male counterparts to rely on nongovernmental organizations. Thus, $93 \%$ of the women, but only $61 \%$ of the men, believe that such organizations should draw attention to the problems of inequality in our society. Women hope that the activity of NGOs might improve the situation. As for other issues unrelated to gender, the views of the men and women are virtually identical. For example, both men and women are equally convinced that science is no longer respected in Russian society (70\% of the male and $71 \%$ the female respondents). Also, both women (100\%) and men (99\%) are sure that inequality is a challenging problem for Russia. This evidence supports the view that women in science and academia recognize gender equality as a specific problem, negatively affecting the position of women in these fields.

\section{Conclusions}

Our study demonstrates that the gender situation in the fields of science and education has changed little in comparison with Soviet times. In spite of many achievements, most women hold lower positions in comparison with men. Women in science and education are in a bad situation. As for women in science, they suffer from thesignificant post-Soviet reduction of funding for science. Also, the ratio of women's to men's salaries in science has changed for the worse. It was $73 \%$ in 2009 but only $71 \%$ in 2011 . Most scientists are concentrated in big cities where the level of pay in science is lower than the average pay in the city's economy. In education 
the ratio of salaries became better. But the salaries are much lower than average for the national economy. So the combination of low salaries in education and science and the consequences of gender inequality manifest themselves most in terms of the material well-being of women who are lecturers and researchers in higher education. Their real situation and their formal status do not correspond to each other. There is a tendency now of their turning into the "new poor", to use the terminology of Professor Rimashevskaia (2003).

\section{References}

Agamova, N. S.; Allathverd'an, A. G. 2001. Rossijskie zhenshchiny v nauke i vysshej shkole: istoriko-nauchnye i naukovedcheskie aspekty, Publichnaja elektronnaia biblioteka. Available on the http://www.bookam.netlauthorlagamova_n_s_allahverdian_a_g_html (Accessed 16 June 2013)

Antonova, J.A. 2010. Diskriminatsia po priznaku pola: perspektivy razvitiia Rossiiskogo antidiskriminatsionnogo zakonodatel'stva. Vlastj. Etnos. Sem'ia: gendernye roli v XXI veke: 27-30. M.: IEA RAS.

Balkienè, K. 2013. Sustainable innovativeness: issues and public policy, Journal of Security and Sustainability Issues 3(2): 53-76. DOI: http://dx.doi.org/10.9770/jssi.2013.3.2(5)

Beljaeva, G.F.; Gorshkova, I.D.; Kostikova, I.V. 2000. Universitetskie zhenshchiny. Shtrihi k portretu, Obshestvennye nauki $i$ sovremennostj 2: 178-185.

Bileišis, M. 2014. Public Sector Control as a Factor in Entrepreneurial Policy: the Case of Lithuania, Entrepreneurship and Sustainability Issues 1(3): 151-161. DOI: http://dx.doi.org/10.9770/jesi.2014.1.3(4)

Bilevičienè, T.; Bilevičiūtė, E. 2015. Influence of employment on strategy of sustainable development implementation, Journal of Security and Sustainability Issues 4(3):520-535. DOI: http://dx.doi.org/10.9770/jssi.2015.4.3(3)S

Bogdanova, I.F. 2004. Zhenshchiny v nauke: vchera, segodnia, zavtra, Sociologicheskie issledovanija, Available on the Internet: http://www.isras.ru/files/File/Socis/2004-01/bogdanova.pdf (Accessed 12 August 2012)

Caurkubule, Ž.; Rubanovskis, A. 2014. Sustainable entrepreneurship through motivation: case of Latvian companies, Entrepreneurship and Sustainability Issues 2(1): 43-48. DOI: http://dx.doi.org/10.9770/jesi.2.1(6)

De Alencar, L.M.; Almeida, H.N. 2013. Economic viability and sustainability of solidarity economy enterprises: a case study on the technological incubator of popular cooperatives of the Catholic University of Salvador, Entrepreneurship and Sustainability Issues 1(2): 92-98. DOI: http://dx.doi.org/10.9770/jesi.2013.1.2(3)

Dzemyda, I.; Zacharevič, G.; Nedelko, Z.2015. Sustainability of international business through trade specialists' education, Journal of Security and Sustainability Issues 4(3): 564-574. DOI: http://dx.doi.org/10.9770/jssi.2015.4.3(6)S

Eflova, M.J.; Fursova, V.V. 2007. Zhenshchina v obrazovanii i nauke. Sbornik materialov po itogam nauchno-prakticheskoi internet konferentsii "Professional'naia kar'era zhenshchin i vyzovy vremeni". Available on the Internet: htppllwww.ostu.rulprometealarticlel (Accessed 12 August 2012).

Ercsey, I. 2012. Perceived quality of life as sustainable development facet, Journal of Security and Sustainability Issues 2(2): 19-30. DOI: http://dx.doi.org/10.9770/jssi.2012.2.2(2)

Figurska, I. 2014.Sustainable entrepreneurship: localization, acquiring and use of knowledge sources in competitive organization, Entrepreneurship and Sustainability Issues 1(4): 210-222. DOI: http://dx.doi.org/10.9770/jesi.2014.1.4(3)

Giessen, H.W. 2015. Sustainable entrepreneurship and peculiarities of media-based learning, Entrepreneurship and Sustainability Issues 2(3): 154-162. DOI: http://dx.doi.org/10.9770/jesi.2014.2.3(4)

Goyal, S.; Sergi, B.S. 2015. Social entrepreneurship and sustainability - understanding the context and key characteristics, Journal of Security and Sustainability Issues 4(3): 269-278. DOI: http://dx.doi.org/10.9770/jssi.2015.4.3(7)

Haritonova, T., 2013. Zhenshchiny v obrazovanii: privilegirovannoe polozhenie ili diskriminatsia. Available on the Internet: http://www.tomb-raider6.narod.ru>lib/vv/variacii...zhenschiny (Accessed 16 June 2013)

Indikatory nauki. 2009. Available on the Internet: http://www.gks.ru/doc_2009/nauka/ind_nauki2009.pdf (Accessed 16 August 2012)

Išoraitė, M. 2013. Motivation tools though lenses of prospective employees, Entrepreneurship and Sustainability Issues 1(2):116-123. DOI: http://dx.doi.org/10.9770/jesi.2013.1.2(6) 
Išoratè, M.; Steiblienė, L.; Mečejienè, G. 2014. If obtained professional competences are suitable for sustainable entrepreneurship: case of Vilnius University of Applied Sciences, Entrepreneurship and Sustainability Issues 1(4): 239-246. DOI: http://dx.doi.org/10.9770/jesi.2014.1.4(6)

Koshkina, A. 2005. V nauke zhenshchinam otvedeny vtorostepennye roli. Available on the Internet: http://science.compulenta.rul2231581 (Accessed 12 August 2012)

Lankauskienè, T. 2014. Accounting productivity in the sectors of economy: methodological aspects, Entrepreneurship and Sustainability Issues 2(2): 98-106. DOI: http://dx.doi.org/10.9770/jesi.2014.2.2(5)

Lankauskienè, T.; Tvaronavičienè, M. 2012. Security and sustainable development approaches and dimensions inn the globalization context, Journal of Security and Sustainability Issues 1(4): 287-297. DOI: http://dx.doi.org/10.9770/jssi.2012.1.4(5)

Laužikas, M.; Dailydaite, S. 2013. Benefits of social capital for sustainable innovation capabilities, Journal of Security and Sustainability Issues 2(3):85-97. DOI: http://dx.doi.org/10.9770/jssi.2013.2.3(7)

Laužikas, M.;Mokšeckienè, R. 2013. The role of creativity in sustainable business, Entrepreneurship and Sustainability Issues 1(1): 1022. DOI: http://dx.doi.org/10.9770/jesi.2013.1(2)

Litvaj, I.; Poniščiaková, O. 2014. Entrepreneurship and quality management, Entrepreneurship and Sustainability Issues 1(4): $204-209$. DOI: http://dx.doi.org/10.9770/jesi.2014.1.4(2)

Mačiulis, A.; Tvaronavičienè, M. 2013. Secure and sustainable development: Lithuania's new role in taking the Presidency of the EU, Journal of Security and Sustainability Issues 3(2): 5-13. DOI: http://dx.doi.org/10.9770/jssi.2013.3.2(1)

Mirskaja E. Z., Martynova E.A. 1993. Zhenshchiny v nauke, Vestnik Rossijskoj Academii Nauk, 8: 693-700.

Mostenska, T.; Bilan, Y. 2015. Sustainable development through enhanced social responsibility, Journal of Security and Sustainability Issues4(3): 536-551. DOI: http://dx.doi.org/10.9770/jssi.2015.4.3(4)S

Narodnoe khoziaistvo SSSR v 1988, 1989. Moscow. Goskomstat SSSR. Available on the Internet: http://www.gks.ru (Accessed 18 July 2013)

Nauka Rossii v tsifrakh. 2011. Zhenshchiny - issledovateli po oblastiam nauki. Moskva: Tsentr issledovanii i statistiki nauki. Available on the Internet: http://www.csrs.rulstatislsc 2011 (Accessed 12 August 2012).

Nauka Rossii. 2003. Moscow: Rosstat Rossii.

Obrazovanie v Rossii. 2003. Moscow: Goskomstat Rossii. Available on the Internet: http://www.gks.ru/wps/wcm/connect/rosstat/ (Accessed 12 August 2012)

Obrazovanie v Rossiiskoj Federatsii. 2010. Available on the Internet: http://www.hse.ru/data/2012/04/25 (Accessed 12 August 2012).

Oreshenkova, N. A. 2007. Vliianie gendernyh stereotipov na kar'ernyi rost zhenshchin. Sbornik materialov po itogam nauchnoprakticheskoi internet konferentsii "Professional'naia kar'era zhenshchin i vyzovy vremeni 1 May - 31 May. Available on the Internet: htpp Iwww.ostu.rulprometealarticle (Accessed December 2010).

Peker, S.; Tvaronavičienė, M.; Aktan, B. 2014. Sustainable risk management: fuzzy approach to volatility and application on FTSE 100 index, Entrepreneurship and Sustainabillity Issues 2(1): 30-36. DOI: http://dx.doi.org/10.9770/jesi.2014.2.1(4)

Prause, G. 2014. A holistic concept for the sustainable evaluation of company shares, Entrepreneurship and Sustainability Issues 2(1): 37-42. DOI: http://dx.doi.org/10.9770/jesi.2014.2.1(5)

Raišienè, A.G.; Jonušauskas, S. 2013. Silent issues of ICT era: impact of techno-stress to the work and life balance of employees, Entrepreneurship and Sustainability Issues 1(2):108-11. DOI: http://dx.doi.org/10.9770/jesi.2013.1.2(5)

Rimashevskaia, N. M. 2003. Chelovek i reformy. Sekrety vyzhivanija. M.: RITS ISEPN: 121-140.

Rossiia v tsifrakh. 2012. Moscow: Rosstat Rossii.

Stolte-Heiskanen, V. 1991. Women in Science. Token Women or Gender Equality. Oxford/New York: Berg, 1-8.

Tarabkova, L. 2014. Model of motivating linked-up with education, Entrepreneurship and Sustainability Issues 2(1): 12-18. DOI: http://dx.doi.org/10.9770/jesi.2014.2.1(2) 
Trud i zaniatost' v Rossii. 2011. Moscow: Rosstat Rossii. Available on the Internet: http:www.gks.ru (Accessed 18 July 2013

Tunčikienè, Ž.; Drejeris, R. 2015. Entrepreneurship ecosystem: methodological approaches to functions' review of public sector institutions, Entrepreneurship and Sustainability Issues 2(3):118-132. DOI: http://dx.doi.org/10.9770/jesi.2014.2.3(1)

Tvaronavičienė, M. 2014. If industrial sector development is sustainable: Lithuania compared to the EU,Entrepreneurship and Sustainability Issues 1(3):134-142. DOI: http://dx.doi.org/10.9770/jesi.2014.1.3(2)

Tvaronavičienè, M.; Lankauskienè, T. 2011. Plausible foreign direct investment'impact on sustainable development Indicators of differently developed countries,Journal of Security and Sustainability Issues 1(1): 25-36. DOI: http://dx.doi.org/10.9770/jssi.2011.1.1(3)

Tvaronavičienè, M.; Šimelytè, A., Lace, N. 2014. Sustainable development facets: exporting industrial sectors from inside, Journal of Security and Sustainability Issues 3(4): 37-44. DOI: http://dx.doi.org/10.9770/jssi.2014.3.4(4)

Varshavskii, A. E. 2009. Modelirovanie social'noi stratifikatsii, Kontseptsii. 2: 14-43.

Vasiliūnaitè, R. 2014. Sustainable development: methodological approaches toward issues, Journal of Security and Sustainability Issues 3(3): 69-75. DOI: http://dx.doi.org/10.9770/jssi.2014.3.3(6)

Vinokurova, N. A. 1999. Muzhchiny i zhenshchiny v nauke: dvoinoi portret, Sociologicheskie issledovanija 4: 12-19.

Voronina, O.A. 1998. Prava zhenshchin v Rossii: issledovanie real'noj praktiki ih sobliudeniia i massovogo soznaniia, MFF: 2: 285-288.

Wahl, M.; Prause, G. 2013. Toward understanding resources, competencies, and capabilities: business model generation approach, Entrepreneurship and Sustainability Issues 1(2): 67-80. DOI: http://dx.doi.org/10.9770/jesi.2013.1.2(1)

Zhenshchiny Rossii. 1995. Moscow: Goskomstat Rossii: 84-85.

Zhenshchiny i muzhchiny Rossii. 2000, 2004, 2008, 2010, 2012. Moscow: Rosstat Rossii. Available on the Internet: http://www.gks.ru (Accessed 12 August 2012)

Natalia Vinokurova (Phd of social sciences) is the head scientific researcher of Central Economics \& Mathematics Institute Russian Academy of Sciences, Moscow, Russia. She is a member of various international women's organizations and is a leader and regular expert of international research projects. She has written and published widely on the subject of gender economics, with significant contributions to international refereed journals, through books, chapters in leading research monographs. She has participated with the reports in the plenary sessions of many international conferences, seminars, and workshops. Research interests: gender equality, gender economics, social economic situation of women and men, women in education and science.

This is an open access journal and all published articles are licensed under a $\underline{\text { Creative Commons Attribution 4.0 International License }}$ 